\title{
Conceptual model of implementation of Lean Production in Russian enterprise
}

\section{Концептуальная модель внедрения Бережливого Производства на предприятии России}

\author{
Received: March 13, $2019 \quad$ Accepted: April 15, 2019
}

\author{
Written by: \\ Sergey V. Novikov \\ https://orcid.org/0000-0001-6921-1760 \\ https://www.scopus.com/authid/detail.uri?authorId=57192318711 \\ elibrary.ru: https://elibrary.ru/author_profile.asp?id=807011 \\ Daniela S. Veas Iniesta ${ }^{7}$ \\ https://orcid.org/0000-0002-8473-0670 \\ https://www.scopus.com/authid/detail.uri?authorId=57204575922 \\ elibrary.ru: https://elibrary.ru/author_profile.asp?id=1028345
}

\begin{abstract}
Taking as basis the research on the introduction and application of lean production (LP), the authors describe the development sequence of LP tools that allowed the formulation of a modern LP tools system. Considering also the classical principles of LP, the article proposes a conceptual model of the multidimensional modern content of LP based on a multi-level understanding of the LP apparatus and takes into account its organizational components and the scale of the required transformations in the organization's activities.
\end{abstract}

Keywords: enterprise management, innovative thinking, lean production, production process, resource saving.

\section{Introduction}

With the development of production in Russia and similar countries and the entry of these countries into the international market, the question arises as to what is the optimal model of production company

\begin{abstract}
Аннотация
На основе обобщения материалов из специализированных источников (литературы, профессиональных сообществ и др.) и результатов зарубежных и отечественных исследований внедрения и применения бережливого производства (БП) авторами описана последовательность развития инструментов БП, что позволило сформулировать современную систему инструментов БП. Опираясь на классические группы принципов БП и современную систему инструментов БП, в статье предложена концептуальная модель многоаспектного современного содержания БП, основанная на многоуровневом понимании аппарата БП и учитывающая организационные компоненты БП и масштабы требуемых преобразований в деятельности организации.
\end{abstract}

Ключевые слова: бережливое производство, инновационное мышление, производственный процесс, ресурсосбережение, управление предприятием.

management (Novikov, 2018; Novikov, Veas Iniesta, 2018). The lean manufacturing program leads to the creation of a learning organization with stable, continuously improving processes. This is a

\footnotetext{
${ }^{6} \mathrm{PhD}$ in Economics, Associate Professor, Head of Institute of Engineering Economics and Humanities, Moscow Aviation Institute (National Research University), Moscow, Russia.

${ }^{7}$ Assistant, Head of Support Center for International Publications, Moscow Aviation Institute (National Research University), Moscow, Russia.
} 
consistent and gradual approach, where leaders form a culture of continuous improvement with a longterm perspective. The application of this method is not limited to the small-size companies, but extends to design and office departments of big enterprises, allowing them to achieve operational excellence.

Recently, "lean-technologies" have become an integral part of modern business and are directly related to the company's economy. It is with the understanding of this fact that the enterprises of high-tech production began their way to implement the principles of lean production, whose development is actively supported by the company's management team (Novikov, Dmitriev, 2018; Novikov, 2018). The transformations on the basis of the concept of lean production are a transition of the enterprise to a new, more qualitative level of functioning that assumes involvement of all employees of the company in the process. In the conditions of a modern reality this process becomes one of key ways of increase of competitiveness of the hi-tech enterprises.

Therefore, the question of the organization of personnel's work in a lean production system becomes more and more actual.

During the transition to "lean-technologies" at the hitech enterprises the human factor plays an important role in the production process. When implementing the principles of lean production at the same time with the improvement of production processes, people's thinking is transformed and the organizational culture of the enterprise is changed. The key factors to ensure the efficiency of lean production are:

- full support of the enterprise's top management;

- developed system of personnel training at all levels;

- involvement of all employees in the process of continuous improvement;

- understanding and enthusiasm of employees;

- transition from mass production to lean production brings significant adjustments to the company's personnel policy. These changes are caused by the following lean production requirements;

- changes in the organizational structure, creation of production cells;

- reduction of the number of personnel to the optimal size, creation of new jobs through the expansion of production;

- training of personnel in lean production principles;
- enrichment of labour and change of motivation methods (Alandarov, Tarkhanovsky, 2017).

The key factor of success in the organization of the production process is the efficient use of human resources, including: full load of all personnel of the company; effective placement of personnel taking into account the qualifications, individual characteristics and capabilities of each employee; advanced training, mastering of workers and specialists of related specialties; provision of opportunities for self-realization, career and professional growth of each employee.

The risk of "human factor" in the implementation of lean manufacturing principles is primarily related to the insufficient qualification of managerial personnel for the project. Often the managers of the enterprise at decision-making on introduction of lean production principles overestimate the time necessary for personnel training and personnel preparation (Dmitriev, Novikov, 2017).

At training it is necessary to convince workers to refuse traditional views on the manufacture organisation, to learn to recognize value, to see a stream of creation of value, to remove barriers on a way of movement of this stream, to pull out a product, and to continuously improve manufacture. Training allows the employees to get acquainted with the world experience of optimization of production processes, master the techniques of problem solving and error prevention, competently organize the working space and study the principles of lean production implementation at the enterprise.

The effective production system of the enterprise includes the system of employees' motivation aimed at transformation of the enterprise activity, further self-realization and recognition of employees' merits. It stimulates those actions of employees, which are aimed at continuous movement of value through the flow, to identify and eliminate all possible losses.

The implementation of lean production approach in high-tech industries can also give a good impetus to many areas of the economy. Lean production cannot be developed and implemented by outside specialists. This can be done only by those who work at the enterprise, know it, and face its problems every day.

\section{Methodology}

The study of the theory and modern foundations of lean production (LP) has shown that a significant 
contribution to the development of LP was made by several foreign authors, scientists, inventors and industrialists, such as Taiichi Ohno $\mathrm{T}$ (somirov, 2008), Masaaki Imai, James James P. Womack,
Daniel Johnson (Womack, Jones, 2003; Womack, Jones, 2005), David Mayer, Jeffrey Liker and Edwards Deming (table 1).

Table 1.

Contribution of American and Japanese scientists to the formation and development of LP

\begin{tabular}{|c|c|}
\hline Researcher & List of works \\
\hline Taiichi Ohno & $\begin{array}{l}\text { Creator of the Toyota production system (1950-1970) } \\
\text { Just-in-Time system (1980) } \\
\text { Single minute Exchange of die system: SMED (1950-1969) } \\
\text { The } 7 \text { types of Waste: MUDA }\end{array}$ \\
\hline Shigeo Shingo & Creator of the visual production management tool "poke-yoke" (1949-1950) \\
\hline $\begin{array}{l}\text { Masaaki Imai } \\
\text { James P. Womack and } \\
\text { Daniel Johnson }\end{array}$ & $\begin{array}{l}\text { Author of the "Kaizen" concept (1986) } \\
\text { The five principles of the "lean production" concept } \\
\text { "Lean thinking" (1996) }\end{array}$ \\
\hline $\begin{array}{l}\text { David Mayer and Jeffrey } \\
\text { Liker }\end{array}$ & $\begin{array}{l}\text { They defined the } 8 \text { wastes of lean production: "the untapped potential of } \\
\text { workers". } \\
\text { "The } 14 \text { principles of doing business on Toyota" }\end{array}$ \\
\hline William Edwards Deming & $\begin{array}{l}\text { The } 14 \text { principles of Deming (1950) } \\
\text { Scientific-rational approach to human management and production operations } \\
\text { based on the "plan-do-see" perspective (1982) } \\
\text { Constribution to the development of quality management (1950-1980) } \\
\text { The theory of deep knowledge (1924) }\end{array}$ \\
\hline Joseph Juran & $\begin{array}{l}\text { "The quality spiral" (1951) } \\
\text { Author of the concept of "Annual Quality Improvement: AQI" (1964) } \\
\text { Constribution to the theory and practice of the "Total Quality Management" } \\
\text { system: TQM (1950-1960) }\end{array}$ \\
\hline Kaoru Ishikawa & $\begin{array}{l}\text { Graphical methof of analyzing cause-effect relationships: Fishbone diagram } \\
\text { (1920) } \\
\text { "Quality circles“ (1962) }\end{array}$ \\
\hline Walter Shewhart & Statistical method of quality management: "Control cards" (1924) \\
\hline Armand W. Feigenbaum & Total Quality Control system (1950) \\
\hline
\end{tabular}

Russian researchers Adler Yu.P., Shper V.L. and Feldman G.N., among others, examined the emergence of LP from the historical point of view. The opinions of foreign and domestic researchers agree that the development of the approach of modern production to the organization and management of the enterprise was influenced by the advances made by G. Ford, F. Taylor, V. Shuhart, J. Juran, I. Holdratt, A. Feichenbum, and others.

The basis of LP roots in its classical groups of principles, and implementation of these principles is carried out due to a certain set of LP

tools. The concretization of the sequence of development of LP tools and the results of domestic research allowed us to formulate the composition of the tools of the modern LP system.

The modern composition of the LP includes 14 tools: organization of the working space (5S), smoothing production and work schedule (Haijunka), constant introspection (Hansey), Just-in-time system (JIT), continuous improvement (Kaizen), reduction of interoperational stocks (Kanban); Material Requirements Planning (MRP), Single-Minute Exchange of Dies (SMED); Standard work, Team work, Total Productive Maintenance (TPM), Total Quality Management (TQM), Visual control and Value Stream Mapping (VSM).

The traditional division of tools, proposed by Taiichi Ohno and Toyoda (Ohno, 1988), was designed with 
the aim to make the company's employees and suppliers understand the ideology of the Toyota production system. The LP tool system consists of 5 blocks:

- principles;

- foundation;

- conceptual framework;

- ideological orientation;

- tactical tools.

The American variant of division of tools and principles of LP was proposed by James Womack and Daniel Johnson.

Based on the classic division tools and principles of LP, and considering the current composition of LP tools, the authors proposed a modern LP tools system (fig. 1).
The content of the modern system of LP tools has three aspects: the fulfillment of delivery conditions, the desire to ensure quality and the reduction of production costs (fig. 1).

The Foundation of the modern system of LP tools is based on the principles of their use: stability (heijunka), standardization work and teamwork (Layker, 2010; Layker, Mayer, 2011).

In tools located in the central part (fig.1) are used to implement and maintain the conceptual framework of the LP.

The conceptual framework of LP (fig. 1) is depicted in the form of several columns of the "LP house": Just-in-time system (JIT), Total Quality Management (TQM) and Total Production Management (TPM).

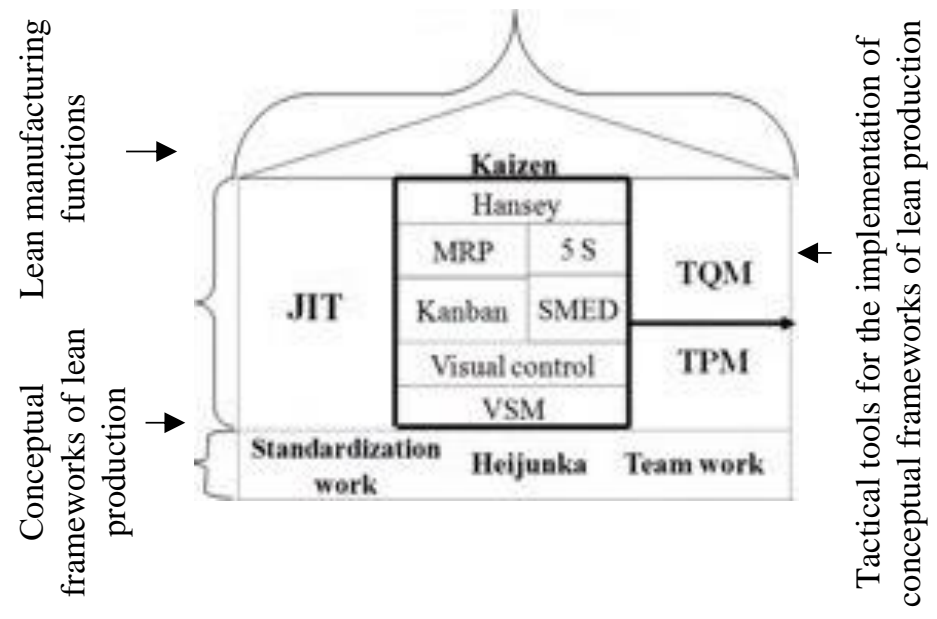

Figure 1. Modern system of lean production tools Ideological orientation of the tools of lean production

The roof of the LP house has a philosophical orientation. The ideology that fils the LP house reveals the desire of continuous improvement of all aspects (Kaizen) (Tsomirov, 2008).

Based on the results of the study of LP principles and tools, a conceptual model of multidimensional modern LP content is proposed.

The use of LP tools (taking into account the principles of LP) primarily depends on the required changes in the company's activities, as well as the depth of implementation of LP in the enterprise

As a result of the study of the theory and practice of the use of $\mathrm{LD}$, the presence of a multi-level understanding of the LP apparatus (philosophical, methodological and instrumental) was revealed.

The levels of understanding of LP determine the possibility of using it in the companies and the specifics of using its tools. At the instrumental level, LP is a set of tools understood as instrument to develop the production at various stages of business processes, the activities of the organization as a whole or in its various functional areas. For example, "Kaizen" at the instrumental level provides an opportunity to improve individual operations, procedures and processes. In contrast to the instrumental one, the methodological level of understanding of LP provides the possibility of systemic application of the LP toolkit. At the methodological level, "Kaizen" is the improvement 
of the system of basic, managing and supporting processes, including methodological, informational and organizational support of decision-making. At the philosophical level, Kaizen is a culture of continuous improvement inherent in the entire staff of the enterprise. The change in the functioning of the enterprise occurs when the level of understanding of LP by the company's management is transformed from the means of solving local problems to the methods of using the tools and philosophy of business management

The use of LP tools also depends on the organizational components of the company's activities (tasks, personnel quality, organization structure, technologies used, etc.). These components are closely related to the levels of understanding of LP. At the instrumental level, the tasks have a local nature. The quality of the personnel, first of all, is determined by the basic qualification skills. Changes in the structure consist on assigning new responsibilities to the staff in the current work. The organizational component "technology" implies the mastering of new LP tools.

The victory of Moscow aviation Institute in 2015 in a competition of the Ministry of Education and Science of Russia allowed us to open a joint project with the company "October" to develop and organize high-tech production of small-size multi-mode onboard Ku-band radar system to equip helicopters and advanced unmanned systems (Dmitriev, Novikov, 2018; Kraev, Tikhonov, Novikov, 2018).

The intended use of the results of the work is the following:

1) on helicopters and aircrafts, radar systems can be applied for monitoring ground situation, data exchange, safety, group flying formation and aerial refueling. When monitoring the ground situation, it can provide solutions to several problems:

- formation of radar images of the earth's surface;

- detection and measurement of coordinates of targets located in the ground (Kanashchenkov, Matveev, Minaev, Novikov, 2017).

2) for unmanned aerial vehicles intended for civil purposes, it can be used to prevent collisions with obstacles, monitor the earth's surface, detect moving ground targets, monitor the state of the atmosphere and water surface, forests, agricultural crops and pipelines, as well as to solve other problems of search and monitoring of the underlying surface and objects on it and control border violations.

\section{Results}

At the methodological level of understanding of LP, changes in technologies will require changes in production methods. The quality of the staff is assessed by its involvement in the process of change. Changes in cross-functional coordination may be necessary in the organizational structure. Setting targets at this level may involve an integrated approach to changes.

At the philosophical level of LP understanding, the tasks has a strategic nature, a great deal of attention is paid to the new value system of the company focused on LP, the organizational management structure is reorganized and the company's integrated system of business processes is developed.

The scale of the required transformations of the organization's activities makes demands on the formulation of the assigned tasks and, therefore, is related both to the organizational elements of the LP and to its levels of understanding. It can be strategic and operational (Novikov, 2018).

With strategic changes, a vision of the future state of activity is projected. That vision determines the need to use higher levels of understanding of the LP and the entire system of organizational components.

The concept of lean production contains principles, methods and tools of production and labor organization at industrial enterprises that differ from traditional approaches. Lean production allows the production of more goods and services with less effort, less space and less cost. As a matter of fact, lean production tools are a complex of methods or methods of practical application of the proposed system. These tools include, in particular, the $5 \mathrm{~S}$ workplace management system, the Just in Time system, Kanban, Kaizen Blitz, rapid changeover (SMED), error prevention (Poka-Yoke), Value Stream Mapping, Total Productive Maintenance (TPM), visualization, one-touch changeover (Onetouch 370 setup), U-shaped cells, etc. One of the main values of lean manufacturing is the subjective feeling of the consumer that the products they need will be delivered at the right time and place.

\section{Conclusion}

Thus, the presented conceptual model of the multidimensional modern content of the LP lies at 
the basis of the proposed methodology for the introduction and development of the LP. It includes the above classical LP principles, the current composition of the LP tools, the possible levels of understanding of the LP in the organization, the organizational components of the LP and the scale of the required transformations in the activities of the enterprise. For the possible application of the theoretical and methodological apparatus in the company's activities, it is necessary to identify the conditions that prompt business leaders to turn to the LP toolkit at various levels of understanding and transformation of the LP with different composition of organizational components. Accordingly, in order to ensure the possibility of applying the developed methodological approach in practice, it is necessary to conduct a study of the practice of applying LP.

\section{References}

Alandarov R.A., Tarkhanovsky K.O. (2017). Comparative analysis of the methodology for organizing research funding on the example of the Russian Federation, Western Europe and Asia. Finances: theory and practice. 6(21), 166-178.

Dmitriev O.N., Novikov S.V. (2017). Conception of managing of fuzzy-institutional meso-level organizational separations in a context of product projects internationalization. European Research Studies Journal. 20(4), 277-289.

Dmitriev O.N., Novikov S.V. (2018). Economic Assessment of Federal Scientific Programs. Russian Engineering Research. 38(4), 326-329.

Kanashchenkov A.I., Matveev A.M., Minaev E.S., Novikov S.V. (2017). New Generation Compact Integrated Radar Systems for Aerial Vehicles. Russian Aeronautics. 60(4), 647-652.

Kraev V.M., Tikhonov A.I., Novikov S.V. (2018). Economic Conversion in the Aviation Industry. Russian Engineering Research. 38(4), 330-333.
Layker J. (2010). Tao Toyota: 14 principles of management of the world's leading company, 5th ed. Moscow: Alpina Publishers.

Layker J., Mayer D. (2011). Toyota Dao Practice. Toyota Management Implementation Guide, 5th ed. Moscow: Alpina Publishers.

Novikov S.V. (2018). Russian Support for Innovation and Export Growth. Russian Engineering Research. 38(4), 305-308.

Novikov S.V. (2018). Strategic Analysis of the Development of High-Technology Manufacturing Facilities. Russian Engineering Research. 38(3), 198-200.

Novikov S.V. (2018). The features of innovative processes in the Russian Federation: analysis of current practices. Espacios. 39(39).

Novikov S.V., Dmitriev O.N. (2018). Vision of Genesis of Presentation of Hi-Tech Project during Competitive Selection. Russian Engineering Research. 38(4), 320-322.

Novikov S.V., Veas Iniesta D.S. (2018). State regulation of the development of the connectivity of the Russian territory. Espacios. 39(45).

Ohno T. (1988). Toyota Production System: Beyond large-scale production. New York: Productivity Press.

Tsomirov V.V. (2008). Kaizen: Strategy of achieving success for a Russian company. Methods of quality management, 5, 4-7.

Womack J., Jones D. (2003). Lean Thinking: Banish waste and create wealth in your corporation. New York: Free Press.

Womack J., Jones D. (2005). Lean Solutions. London: Simon \& Schuster. 